\title{
Demand side management of the built environment for sustainable energy
}

\author{
A. Arteconi ${ }^{1}$, F. Polonara ${ }^{2} \&$ C. Brandoni ${ }^{1}$ \\ ${ }^{1}$ Università degli Studi e-Campus, Italy \\ ${ }^{2}$ Department of Industrial Engineering and Mathematical Sciences, \\ Marche Polytechnic University, Italy
}

\begin{abstract}
The current electricity market, characterized by the increasing energy demand and growing penetration of renewable energies, presents a number of challenges to grid operators and is moving toward the Smart Grid infrastructure, which includes the Demand Side Management (DSM) concept. Due to the energy consumption involved, an interesting and promising field of the application of DSM is the management of the electrically driven thermal systems in buildings. This study focuses on energy demand in buildings for heating and cooling produced by heat pumps (HP), which will hopefully have an increasing penetration in the field of room air-conditioning, given the potential improvement in energy efficiency. Moreover, heat pumps are seen as a promising technology for load management in the built environment, also coupled with Thermal Energy Storage (TES) systems to shift electrical loads on the basis of grid request. The main purpose of this paper is to analyze the DSM potential of heating and cooling loads in residential buildings while using heat pumps. Different building characteristics, plant configurations and DSM strategies will be considered.
\end{abstract}

Keywords: demand side management, heat pumps, thermal energy storage, load shifting, built environment.

\section{Introduction}

The current electricity market, characterized by the increasing energy demand and growing penetration of renewable energies, presents a number of challenges to grid operators and is moving toward the Smart Grid infrastructure, which 
includes the Demand Side Management (DSM) concept. DSM is defined as any program designed to influence the customer's energy use. The focus of DSM is on changing the shape of the electrical load profile and thereby helping to optimize the whole power system from generation, to delivery, to end use [1]. Due to the energy consumption involved, an interesting and promising field of application of DSM is the management of electrically driven thermal systems in buildings, e.g. heat pumps (HP). The introduction of newer, more efficient space and water heating technologies is essential if the target of reducing greenhouse gas (GHG) emissions imposed by EU energy policy is to be achieved. The role of heat pumps in the effort to reduce energy demand is well recognized and their market share is increasing considerably [2]. Considering that buildings account for $40 \%$ of the total energy consumption in the European Union, mainly for space heating and hot water [3], there are relatively large heating, cooling and hot water demands that can be controlled, adapted and/or enhanced to perform a DSM function. A proper DSM strategy addressed to managing electricity consumption for heating and cooling could be effective for the purposes of matching demand and unpredictable electrical energy production. This is also in line with the EU commitments for 2020 and with the guidelines of the building roadmap [4].

The purpose of this paper is to analyze the effect of the management of thermal loads on the electricity consumption in the built environment with the two main constraints being the request from the electricity market and the thermal comfort inside the building. The approach to the problem will be bottom-up, meaning that the focus will be on the final user of the building.

\section{Methods}

The analysis was performed by means of sample cases aimed at showing how different buildings with different heating/cooling systems behave under Demand Side Management strategies. A dynamic simulation tool was used for their representation. The setting scenario is a town of central Italy, so that both heating and cooling demand are present.

In this section the sample cases are shown in detail, then the simulation models are described as well as the considered DSM strategies.

\subsection{Sample cases}

As sample buildings, two typical Italian multi-family residential buildings were considered, one built in the period of 1990 to 2005 and one in the aftermath of 2010 under new building regulation [5]. They are representative of the most recent existing building stock, but also of the target for retrofitting actions [6]. Moreover, in order to take into account future trends, even a Passive House building was included in the evaluations. A $100 \mathrm{~m}^{2}$ apartment (with three external walls and set at an intermediate floor of the building) was used in the analysis. The main building features are reported in table 1 . 
The heating, cooling and Domestic Hot Water (DHW) were produced by air source heat pumps. In the heating mode, the distribution systems can be composed of radiators or underfloor heating systems; in the cooling mode, an air conditioning system or an underfloor cooling system can be used. Moreover EU prescriptions impose that after 2030 new buildings have to be nearly-zero energy buildings [7], for this reason our Passive House sample is also equipped with shading devices, mechanical ventilation with heat recovery, hot water solar panels and PV panels.

Table 1: Main building features.

\begin{tabular}{|c|c|c|c|c|c|c|}
\hline Sample case & Building age & $\begin{array}{c}\text { Area } \\
\mathrm{m}^{2}\end{array}$ & $\begin{array}{c}\mathrm{S} / \mathrm{V} \\
\mathrm{m}^{-1}\end{array}$ & $\begin{array}{c}\text { Window } \\
\text { ratio }^{2}\end{array}$ & $\begin{array}{c}\mathrm{U} \text { walls } \\
\mathrm{W} / \mathrm{m}^{2} \mathrm{~K}\end{array}$ & $\begin{array}{c}\mathrm{U} \text { windows } \\
\mathrm{W} / \mathrm{m}^{2} \mathrm{~K}\end{array}$ \\
\hline $\mathrm{A}$ & 1990 & 100 & 0.37 & $10 \%$ & 0.60 & 2.2 \\
\hline $\mathrm{B}$ & 2010 & 100 & 0.37 & $10 \%$ & 0.35 & 1.4 \\
\hline $\mathrm{C}$ & Passive House & 100 & 0.37 & $10 \%$ & 0.12 & 0.80 \\
\hline
\end{tabular}

\subsection{Simulation models}

Simulation models for the sample cases were realized. The transient simulation of the system was performed by means of TRNSYS [8]. It is a well known simulation environment for dynamic evaluations and it is composed of different models that represent buildings and plant equipments, including control strategies, occupant behaviour, alternative energy systems (wind, solar, photovoltaic, hydrogen systems), etc.

Different building-plant configurations were evaluated and the most representative for the considered building stock were analysed in detail, in particular:

- Case A: typically, 1990's buildings in Italy are equipped with radiators supplied by natural gas boilers. Here we assumed to retrofit the production system with an air-to-water heat pump, keeping the radiators. In fact they can continue satisfying the heat demand, at the lower supply temperatures of the heat pump, since generally they were over-dimensioned in their design stage. In addition, certain heat loss can be avoided through operation at low temperatures, providing savings in heat production [9]. In this case a Thermal Energy Storage (TES) is always necessary for transient operation, shown in fig. 1(a). The cooling load, instead, is provided by an air-to-air heat pump with split system air-conditioning.

- Case B: for new houses built with the most recent Italian building regulation the best available technologies are considered. Thus an air-towater heat pump coupled with underfloor distribution system for heating and cooling is used. No TES are included in the model, because, as shown elsewhere [10], the thermal mass involved in these systems is enough to manage transient operation, shown in fig. 1(b). Just a small buffer tank is used to smooth the operation. 
- Case C: this is a nearly zero-energy building, following the Passive House prescriptions for the building envelope and it is also equipped with shading devices (lowered when the total irradiation on the façade exceeds $250 \mathrm{~W} / \mathrm{m}^{2}$, while it is raised again when the irradiation falls below $150 \mathrm{~W} / \mathrm{m}^{2}$ ), with mechanical ventilation with heat recovery, hot water solar panels and PV panels (1 kWp), as shown in fig. 1(b).

The production unit and the distribution system were designed for the sample cases and their main features are reported in table 2. Typical design rules were applied: in the case of the radiators system the heat pump capacity was set equal to the building design load (winter design outdoor temperature $-2^{\circ} \mathrm{C}$ and indoor temperature $20^{\circ} \mathrm{C}$ ), while the radiators capacity is oversized of about $50 \%$. In the case of the underfloor system the heat pump capacity was set as equal to $80 \%$ of the building's design load. Heat pump performances are set using the manufacturer's data.

For a typical Italian house an average of three occupants per apartment is well representative of the actual situation. Two different occupant behaviour patterns were considered in the simulation: (i) occupants at home for the whole day the all week, typically retired people and (ii) occupants at home in the morning and in the evening during working days and at home for the whole day during the weekend, typically working people. The gain per person assumed is $120 \mathrm{~W}$.

The building occupation affects the schedule of the heating/cooling system with radiators. In Case A with the first occupants pattern the system is on from

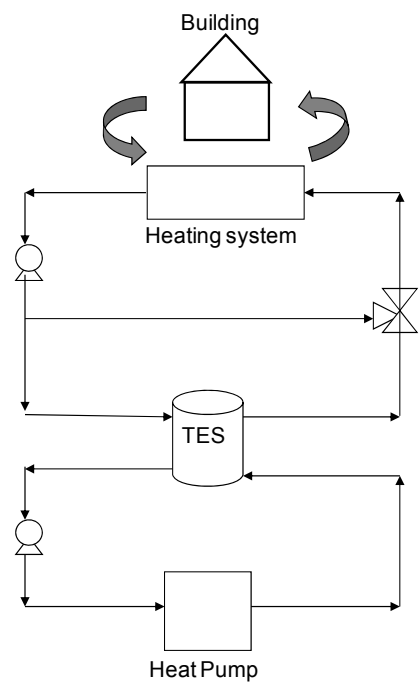

(a)

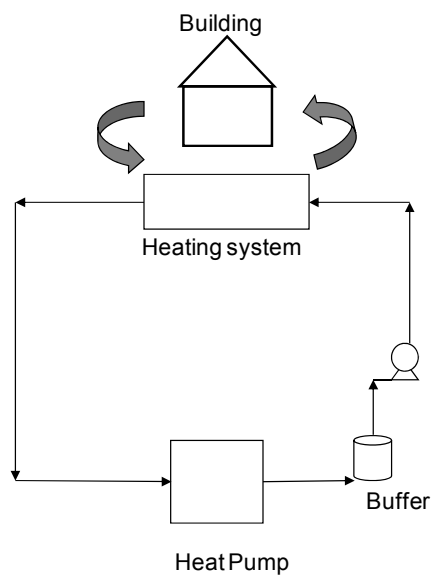

(b)

Figure 1: Schematic of the heating systems of Case A (a), Case B and Case C (b) [10]. 
$6: 00 \mathrm{~h}$ to $22: 00 \mathrm{~h}$, while with the second pattern the system is from $6: 00$ to $9: 00 \mathrm{~h}$ and from 16:00 to 22:00h. In Case B, instead, the underfloor system is always running, independently of the occupants' behaviour. Moreover the switching on/off temperature set-points are: outside ambient temperature $\left(\mathrm{T}_{\mathrm{air}}=15^{\circ} \mathrm{C} \pm 1^{\circ} \mathrm{C}\right.$ for heating), indoor temperature ( $\mathrm{T}_{\text {house winter }}=20^{\circ} \mathrm{C} \pm 0.5^{\circ} \mathrm{C} ; \mathrm{T}_{\text {house summer }}=24^{\circ} \mathrm{C} \pm 0.5^{\circ} \mathrm{C}$ ), and floor surface temperature $\left(\mathrm{T}_{\text {slab_winter }}=29^{\circ} \mathrm{C} \pm 1^{\circ} \mathrm{C}\right.$; $\left.\mathrm{T}_{\text {slab_summer }}=17^{\circ} \mathrm{C} \pm 1{ }^{\circ} \mathrm{C}\right)$ or radiator surface temperature $\left(\mathrm{T}_{\mathrm{s}}=55^{\circ} \mathrm{C} \pm 1^{\circ} \mathrm{C}\right)$. When the TES unit is included in the system, the maximum temperature inside the tank is also taken into account $\left(\mathrm{T}_{\text {tank }}=45 \div 55^{\circ} \mathrm{C}\right.$ for the radiators). In the latter case, the tank temperature controls the starting and stopping of the heat pump, while the other variables control the pump serving the heating distribution system.

Infiltration of the peripheral zone is modelled as a constant air flow of $0.3 \mathrm{ACH}$ (Air Changes per Hour), while for Case A and B natural ventilation in presence of occupants is also considered and assumed at $0.4 \mathrm{ACH}$. Ancona (central Italy) weather available in TRNSYS is the weather file used in the model. The simulation time step is 6 minutes.

Table 2: Heating and cooling systems features for Case A, Case B and Case C.

\begin{tabular}{|c|c|c|c|c|}
\hline & & Case A & Case B & Case C \\
\hline Heat distribution system & & radiators & floor & floor \\
\hline radiators $\mathrm{q}_{\text {design }}$ & $\mathrm{kW}$ & 4 & & \\
\hline$\Delta \mathrm{T}$ & ${ }^{\circ} \mathrm{C}$ & 10 & 5 & 5 \\
\hline \multicolumn{5}{|l|}{ Chiller } \\
\hline$Q_{\text {load }}$ & $\mathrm{kW}$ & 3 & 1.5 & 1 \\
\hline $\mathrm{COP}$ & $\mathrm{kW}$ & 2.0 & 3 & 3 \\
\hline $\mathrm{P}$ & $\mathrm{kW}$ & 1.5 & 0.5 & 0.3 \\
\hline \multicolumn{5}{|l|}{ Heat pump } \\
\hline $\mathrm{Q}_{\text {load }}$ & $\mathrm{kW}$ & 2.5 & 1.5 & 1 \\
\hline $\mathrm{COP}$ & $\mathrm{kW}$ & 2.3 & 3 & 3 \\
\hline $\mathrm{P}$ & $\mathrm{kW}$ & 1.09 & 0.5 & 0.3 \\
\hline \multicolumn{5}{|l|}{ Tank } \\
\hline Capacity (standard) & 1 & 100 & & \\
\hline Capacity ( 2 h buffer) & 1 & 700 & & \\
\hline Capacity (12 h buffer) & 1 & & & \\
\hline
\end{tabular}




\subsection{DSM strategies}

In general, DSM programs can be aimed at peak clipping, valley filling, load shifting and strategic conservation. Several options can be implemented to make the energy demand follow the energy production more or less dynamically, among them three different types of DSM mechanisms were considered in this paper:

(i) a peak shaving strategy, (ii) a random request of switching on/off the system and (iii) a night load shifting strategy.

The peak shaving strategy (DSM1) is aimed at reducing the energy consumption during peak hours for the electricity demand. It is particularly useful to reduce or preserve the maximum generation capacity of power plants and thus to limit the electricity production cost. In Italy the peak periods are between 11:00 and 13:00h and between 19:00 and 21:00h in winter, and between 11:00 and 13:00h in summer [11].

The random request strategy (DSM2), instead, wants to show what happens when the grid asks for short switching off periods with several repetitions during the working hours of the day. This strategy represents the intermittent behaviour of renewable energies (particularly wind energy) that ask for allocation of variable loads and if integrated in the production mix could cause unbalanced production or shortages periods, so that the utility needs a backup generation facility and storage systems or it can request to the final users to adapt their demand on the basis of energy availability. In the latter case, generally the utility sends different signals to turn on/off those end users devices suitable for such operating conditions [12]. For the case under study a switch off time of 15 minutes per hour, randomly positioned, was assumed.

Eventually the night load shifting strategy (DSM3) allows the heat pump to work only at night time, while being off from 8:00 to 20:00 so as to reduce the daytime load and increase the night time one. This helps a more uniform load distribution during the whole day and consequently a more stable power production.

\section{Results and discussion}

The first step of the analysis was aimed at characterizing the different buildings and plant types under the point of view of their dynamic behaviour. The thermal heaviness of a building can be quantified by means of the building's thermal time constant [13], strictly related to the cooling down period. We assessed, by means of the dynamic simulation, that when the modelled buildings are left in a cold climate without heating it takes about 30 hours in Case A and about 50 hours in Case B to decrease the internal temperature of $2^{\circ} \mathrm{C}$, from $20^{\circ} \mathrm{C}$ to $18^{\circ} \mathrm{C}$. Then to heat the building up again, it takes just 15 minutes for a radiators heating system and about 3 hours for an underfloor heating system. The cooling down period represents the thermal inertia of the building, while the heating up period the response speed of the distribution system. Thus, as expected, Case A has lower thermal inertia than Case B and a faster distribution system.

Simulations for the different configurations were run and main results are reported in table 3 , showing thermal comfort and energy consumption. The 
overheating hours are defined as the number of occupation hours when the indoor temperature is higher than $26^{\circ} \mathrm{C}$, while the underheating hours when the indoor temperature is lower than $18^{\circ} \mathrm{C}$. In order to evaluate the incidence of the discomfort hours, their percentage respect to the total daily hours of building occupancy was calculated (about 5800 hours for the retired occupant profile and about 4000 hours for the working occupant profile). A discomfort of up to $5 \%$ is considered acceptable. The total electrical consumption is assessed and its breakdown is also provided (divided in consumption of heat pump, chiller and pumps).

Table 3: Discomfort and energy consumption results for different configurations.

\begin{tabular}{|c|c|c|c|c|c|c|c|c|c|c|c|c|}
\hline \multirow[t]{2}{*}{ Case } & \multirow[t]{2}{*}{ Occupant } & \multirow[t]{2}{*}{ Strategy } & \multirow[t]{2}{*}{ Tank } & \multirow[t]{2}{*}{$\begin{array}{c}\text { T_set, } \\
\text { cold }\end{array}$} & \multicolumn{3}{|c|}{ Discomfort } & \multicolumn{5}{|c|}{ Energy } \\
\hline & & & & & $\begin{array}{c}\text { over- } \\
\text { heating }\end{array}$ & \begin{tabular}{|c|} 
under- \\
heating
\end{tabular} & impact & HP & Chiller & Pumps & El_tot & var \\
\hline & & & 1 & ${ }^{\circ} \mathrm{C}$ & $\mathrm{h}$ & $\mathrm{h}$ & $\%$ & $\mathrm{kWh}$ & $\mathrm{kWh}$ & $\mathrm{kWh}$ & $\mathrm{kWh}$ & $\%$ \\
\hline A & retired & std & 100 & 24 & 1.6 & 4.4 & 0.1 & 782 & 1710 & 124 & 2615 & \\
\hline A & retired & DSM1 & 700 & 22 & 11.4 & 4.2 & 0.3 & 800 & 2420 & 130 & 3351 & 28.1 \\
\hline A & retired & DSM1 & 700 & 24 & 37 & 4.2 & 0.7 & 799 & 1750 & 129 & 2676 & 2.3 \\
\hline A & retired & DSM2 & 100 & 24 & 47 & 26 & 1.3 & 738 & 1511 & 126 & 2376 & -9.2 \\
\hline A & retired & DSM2 & 100 & 22 & 10.3 & 26.4 & 0.6 & 739 & 2130 & 126 & 2995 & 14.5 \\
\hline A & retired & DSM3 & 1000 & 22 & 129 & 72 & 3.5 & 908 & 1830 & 154 & 2891 & 10.6 \\
\hline A & working & std & 100 & 24 & 19.9 & 58.1 & 1.9 & 695 & 1309 & 110 & 2115 & \\
\hline A & working & DSM1 & 700 & 24 & 33.8 & 74.1 & 2.7 & 727 & 1370 & 115 & 2210 & 4.5 \\
\hline A & working & DSM2 & 100 & 24 & 90 & 116 & 5.1 & 652 & 1160 & 110 & 1927 & -8.9 \\
\hline A & working & DSM2 & 700 & 22 & 46 & 68 & 2.8 & 732 & 1680 & 114 & 2526 & 19.5 \\
\hline A & working & DSM3 & 1000 & 22 & 52 & 31 & 2.1 & 903 & 1760 & 147 & 2807 & 32.7 \\
\hline B & retired & std & 0 & 24 & 0 & 0 & 0 & 649 & 171 & 138 & 998 & \\
\hline B & retired & DSM1 & 0 & 24 & 0 & 1 & 0 & 638 & 169 & 135 & 942 & -1.7 \\
\hline B & retired & DSM2 & 0 & 24 & 0 & 0 & 0 & 641 & 159 & 133 & 933 & -2.6 \\
\hline B & retired & DSM3 & 0 & 24 & 34 & 423 & 7.8 & 562 & 130 & 112 & 804 & -16 \\
\hline $\mathrm{C}$ & retired & std & 0 & 24 & 0 & 0 & 0 & 459 & 102 & 120 & 681 & \\
\hline $\mathrm{C}$ & retired & DSM1 & 0 & 24 & 0 & 0 & 0 & 450 & 97 & 117 & 664 & -28.2 \\
\hline $\mathrm{C}$ & retired & DSM2 & 0 & 24 & 0 & 0 & 0 & 456 & 96 & 118 & 670 & -27.6 \\
\hline $\mathrm{C}$ & retired & DSM3 & 0 & 24 & 0 & 457 & 7.8 & 392 & 88 & 102 & 582 & -37.1 \\
\hline
\end{tabular}


The two different occupant behaviours, described in section 2.2, were used for Case A with radiators, while for Case B and C only the retired occupants profile was considered, in fact, being the schedule of the underfloor system running 24/7 anyway, it represents the most critical configuration for comfort performance.

\subsection{Case A}

Considering that this building-plant configuration was defined a low thermal inertia system, additional means are necessary to allow the needed flexibility under Demand Side Management strategies. In particular in heating mode a bigger storage tank was considered (100 litres for the standard configuration, 700 litres for 2 hours of flexibility and 1000 litres for 12 hours of flexibility), while in cooling mode, not having any buffer device, a lower cooling temperature set-point was set, in order to pre-cool the building during "on" periods (the cold set-point was decreased from $24^{\circ} \mathrm{C}$ to $22^{\circ} \mathrm{C}$ ).

As far as the peak shaving strategy (DSM1) is concerned, it is evident that a 700 litres tank is enough for 2 hours flexibility, keeping the underheating hours the same as for the standard case. The reduced cooling set-point $\left(22^{\circ} \mathrm{C}\right)$, instead, helps to lower the overheating hours, even if the standard set-point $\left(24^{\circ} \mathrm{C}\right)$ also allows an adequate performance.

The random strategy (DSM2) asks for switching off periods of 15 minutes, so a 100 litres tank can be used. This strategy is particularly critical for such configuration, in fact the radiators system is a fast response system, meaning that it heats up fast, but it cools down rapidly as well. Thus repetitive short switching off periods badly affect the thermal comfort, even if it is possible to maintain the total discomfort hours lower than $5 \%$ of the total running hours.

The night load shifting strategy (DSM3) is the most critical, especially in summer, being the plant off for 12 hours, but also in this case the comfort performance is acceptable.

In general, the electricity consumption increases under Demand Side Management strategies, because more energy is required to heat the additional storage tanks or to pre-cool the building in order to shift the demand to different time periods.

\subsection{Case B}

Case B represents a high thermal mass building-plant system and such thermal inertia is used to guarantee the necessary flexibility, without any additional device. The results highlight that this configuration works very well under DSM1 and DSM2 mechanisms without any detrimental of the thermal comfort. Moreover, since no thermal storages are added and thanks to the good performance of the building envelope, the total energy consumption is reduced with respect to the referenced standard case.

Only for the DSM3 strategy the thermal mass is not enough to allow a 12 hours switching off period. In this case an additional storage is needed, but with a lower volume requested in the configuration of Case A. 
In fig. 2 the load curves and the redistribution of the heat pump energy consumption during a typical winter day is shown under different DSM strategies.

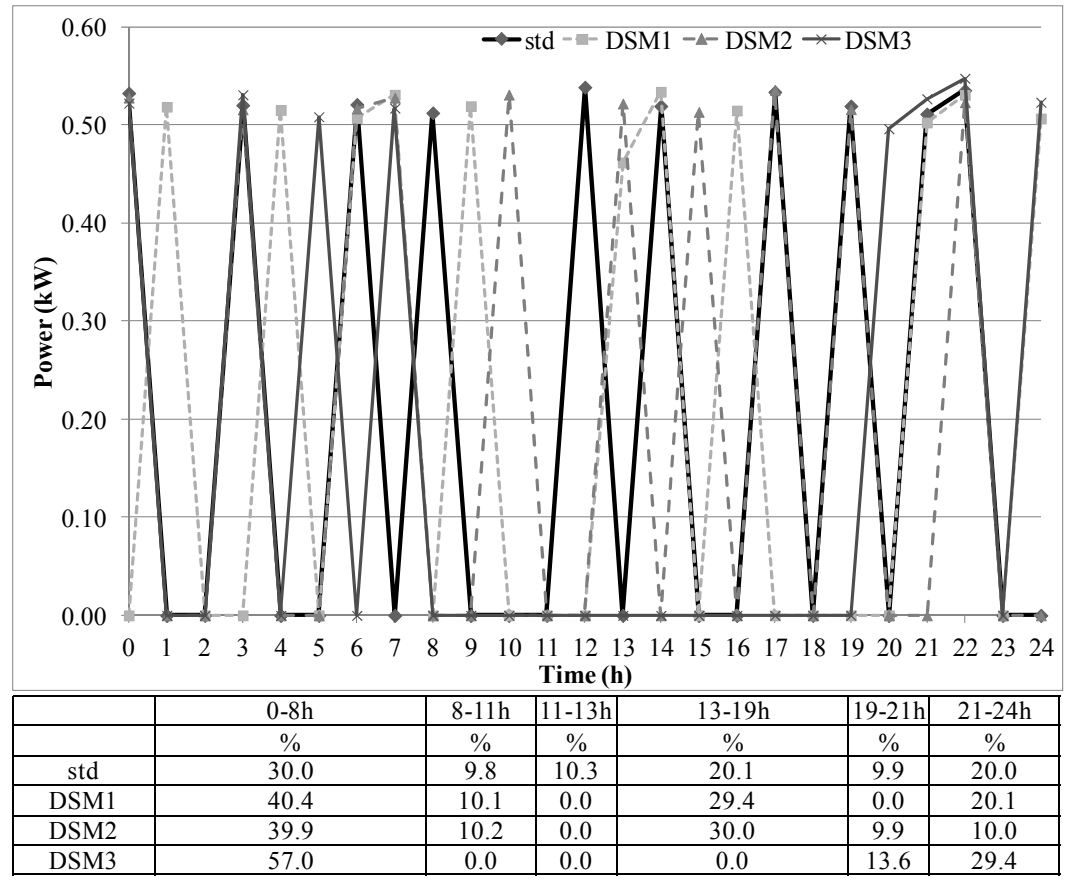

Figure 2: Heat pump load curves under different DSM strategies for a typical winter day for Case B.

\subsection{Case C}

The nearly-zero energy apartment shows a behaviour similar to Case B under DSM strategies: no additional storage devices are requested to keep the internal thermal comfort at the same level as in the standard case, apart from the mechanism of night load shifting. Also in this configuration an external TES is required in order to provide 12 hours of flexibility in winter.

However further considerations are necessary to underline the role of a nearly zero energy building in the Demand Side Management framework. In fact such buildings are provided with domestic renewable production plant, especially solar panels for domestic hot water and PV panels. Assuming to install a $1 \mathrm{kWp}$ PV panel with an electric efficiency of $12 \%$, the annual electricity production would be $1128 \mathrm{kWh}$, which is double of the HP yearly energy consumption. This means that, in theory, a nearly zero energy building is not affected at all by the requests from the grid because it can self-produce its own energy demand. Actually the latter consideration is not completely true since the building energy demand does not always match the local renewable energy plants production. 
In the considered Case $\mathrm{C}$, for example, fig. 3 shows the $\mathrm{PV}$ electricity production vs. the heat pump energy demand in a typical winter (a) and summer day (b). It is evident that the PV electricity is not always available when needed and in winter the production can be lower than the demand. This issue could be solved with energy storages: a battery to store the excess of electricity to be used later, a TES to store the thermal energy for a later use or seasonal energy storage to balance the surplus of summer production with the poverty of winter production.

If a nearly zero energy building can be really independent from the grid, it can no more be considered as an instrument to match electricity production and demand at the grid level.

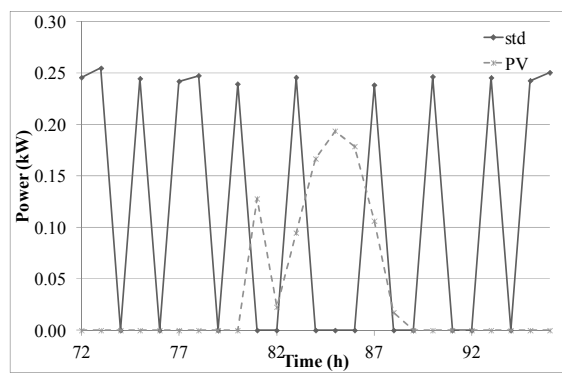

(a)

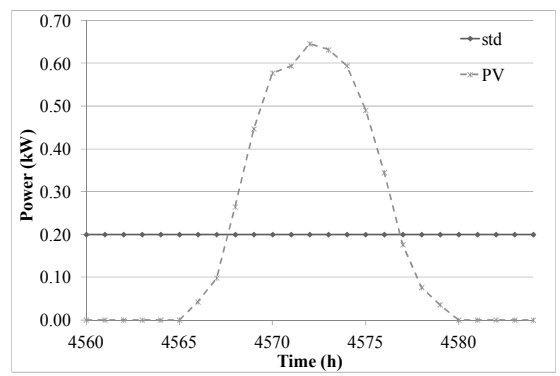

(b)

Figure 3: $\quad$ PV electricity production vs. heat pump energy demand in a typical winter (a) and summer day (b) for Case C.

\section{Conclusions}

The purpose of this paper was to evaluate the role of the built environment in the Demand Side Management framework. In fact buildings have relatively large heating, cooling and hot water demands that can be controlled, thus helping to adapt the demand to variable production energy sources and to implement the Smart Grid concept. In particular, thermal comfort and energy consumption of several building-plant configurations were analysed under different DSM strategies by means of dynamic simulation.

The main conclusions that can be drawn from this analysis are:

- Low thermal inertia buildings and/or fast response heating/cooling systems (e.g. radiators) asks for additional thermal storage systems to guarantee the flexibility requested by the grid.

- High thermal inertia buildings and/or slow response heating/cooling systems (e.g. underfloor systems) do not need additional storage devices, unless very long flexibility periods (e.g. $12 \mathrm{~h}$ ) are requested by the grid.

- The TES systems size depends on the length of flexibility period requested and on the building envelope features. The tank maximum capacity is determined on the basis of space constraints (a technical 
room at building level is needed to include the equipment of different apartments) and economic evaluations.

- In presence of a TES the energy demand of the systems generally increases, because a surplus of energy has to be provided to the storage.

- If the participation to DSM programs causes an increase of the energy consumption, a proper incentive scheme is necessary to involve the users in such programs.

- The introduction of external storage systems coupled with fast response heating/cooling systems look much more effective on thermal comfort than precooling/preheating mechanisms.

- The user behaviour has a bigger influence in presence of low thermal inertia systems.

- The peak shaving strategy shows the easier implementation in the considered buildings, while the random request strategy is particularly critical for fast response heating/cooling systems, because it causes repetitive switching off of the plant. The night load shifting strategy, instead, has a big impact on the system design in order to make it suitable for long stopping periods.

- The increasing performance of building envelope decreases the impact of a single dwelling on the global energy consumption and asks for a higher penetration rate of electrically driven heating/cooling system in DSM programs in order to make the load modification effective at the grid level.

- Nearly zero energy buildings are examples of local Demand Side Management strategies, provided with production and storage systems, but, being mainly independent from the grid, are not interesting to be used in Smart Grid framework.

\section{Acknowledgement}

This project is funded by the European Union under the Marie Curie Action's IRSES (POREEN).

\section{References}

[1] Faruqui, A., Chamberlin, J.H., Principles and practice of demand-side management, EPRI, Palo Alto, 1992.

[2] EHPA, European Heat Pump Association, Outlook 2011 - European Heat Pump Statistics.

[3] European Parliament, EU Directive on the Energy Performance of Buildings (recast) (2010/31/EU), 19 May 2010.

[4] Energy Efficient Building PPP, Research and Innovation Roadmap Draft, July 2012. www.e2b-ei.eu./ 
[5] Italian legislative Decree 311/2006. "Disposizioni correttive ed integrative al decreto legislativo 19 agosto 2005 , n. 192, recante attuazione della direttiva 2002/91/CE, relativa al rendimento energetico nell'edilizia".

[6] Corrado, V., Ballarini, I., Corgnati, S.P., National scientific report on the TABULA activities in Italy, Politecnico di Torino, Torino, Italy, 2012.

[7] Directive 2010/31/EU of the European parliament and of the council of 19 May 2010 on the energy performance of buildings (recast).

[8] Klein, S.A., et al., TRNSYS manual, University of Wisconsin-Madison, 2009.

[9] Tol, H.I., Svendsen, S., Improving the dimensioning of piping networks and network layouts in low-energy district heating systems connected to low-energy buildings: A case study in Roskilde, Denmark, Energy 38 pp. 276-290, 2012.

[10] Arteconi, A., Hewitt, N.J., Polonara, F., Domestic demand-side management (DSM): Role of heat pumps and thermal energy storage (TES) systems, Applied Thermal Engineering 51, pp. 155-165, 2013.

[11] Terna, Carichi, 2012. http://www.terna.it/.

[12] Cecati, C., Citro, C., Siano, P., Combined Operations of Renewable Energy Systems and Responsive Demand in a Smart Grid, IEEE Transactions on sustainable energy, Vol. 2, n. 4, 2011.

[13] Karlssona, J., Wadsöa, L., Öberg, M., A conceptual model that simulates the influence of thermal inertia in building structures, Energy and Buildings 60 pp. 146-151, 2013. 